\title{
Pengenalan Konsep Diri Anak Melalui Visual Learning di TK Annida Ya Fatimah Jepat Lor Tayu Pati, Jawa Tengah.
}

\author{
Luluk Elyana \\ Dosen PG-PAUD IKIP Veteran Semarang \\ lulukelyana76@gmail.com
}

\begin{abstract}
Tujuan dari penelitian ini adalah melihat fenomena pembentukan konsep diri anak melaalui pembelajaran media visual dan mendeskripsikan bagaimana media visual yang merupakan dasar teknologi dan informasi dapat menjadi alternatif bagi guru PAUD di TK Annida Ya Fatimah Jepat Lor Tayu Pati. Metode penelitian menggunakan pendekatan kualitatif-fenomenologi. Variabel dalam penelitian ini adalah konsep diri dan digital learning. Subyek penelitian yang digunakan adalah anak usia 2 - 6 tahun di KB - TK Annida Ya Fatimah Jepat Lor Tayu Pati. Instrumen penelitian menggunakan tehnik trianggulasi yaitu wawancara, dokumentasi dan observasi terhadap subyek penelitian. Hasil penelitian menunjukkan adalah pada kegiatan mulai perencanaan, peleksanaan dan evaluasi. Melalui media ini dapat membantu proses pembelajaran yang menyenangkan bagi anak sehingga tujuan pembelajaran yaitu pengenalan konsep diri akan tercapai.
\end{abstract}

\section{Kata Kunci: Konsep Diri, Visual Learning, Anak usia 2 - 6 tahun}

The purpose of this study is to look at the phenomenon of the formation of children's self concept through visual media learning and describe how visual media is the basis of technology and information can be an alternative for early childhood teachers in kindergarten Annida Ya Fatimah Jepat Lor Tayupati Research method using qualitative phenomenology approach. Variables in this research is self concept and digital learning. The subjects of the study were children aged 2 -6 years old in KB-TK Annida Ya Fatimah Jepat Lor Tayu Pati. The research instrument using triangulation technique is interview, documentation and observation to research subject. The result of the research shows that the activity starts planning, peleksanaan and evaluation. Through this media can help the learning process is fun for children so that the learning objectives of the self-concept recognition will be achieved.

Keywords: Self Concept, Visual Learning, Children 2-0 years old 


\section{PENDAHULUAN}

Masa kanak - kanak merupakan masa yang terpanjang dalam rentang kehidupan manusia. Masa dimana individu relatif tidak berdaya dan bergantung pada orang lain. Usia kanak - kanak seringkali dianggap tidak ada akhirnya sewaktu menunggu pengakuan dari masyarakat . Masa ini dimulai setelah melewati masa bayi yang penuh ketergantungan yaitu usia dua tahun sampai matang secara sexual (Hurlock, 2012). Kanak - Kanak awal secara kronologis adalah anak yang berada pada usia $2-6$ tahun. Walaupun masih terikat dan memfokuskan diri pada hubungan dengan orang tua dan keluarga tetapi masa ini dilengkapi dengan kemandirian, kemampuan kontrol diri (self control) dan hasrat untuk memperluas pergaulan dengan anak - anak sebaya . Pergaulan yang makin luas ini akan mengurangi kelekatan emosi dengan orang tua, mengurangi egosentrisme, mengurangi sifat irasional, karena dalam pergaulan itu masing - masing anak saling mengkritik, mencela, mengejek dan mungkin terjadi konflik, pertengkaran yang kemudian diikuti dengan proses pembuatan kompromi, adaptasi norma - norma sosial yang baru. Meningkatnya pemahaman tentang bagaimana anak - anak berkembang dan belajar telah muncul penekanan yang lebih besar pada Pendidikan Anak Usia Dini diantaranya Kelompok Bermain (KB), Taman Kanak - Kanak (TK) atau pendidikan pra sekolah yang diikuti anak - anak usia 2 - 6 tahun (Depdiknas, 2015). Pendidikan berpusat pada anak melibatkan seluruh anak dan mencakup kepedulian akan perkembangan fisik, kognitif dan sosial anak. Pembelajaran diorganisasikan sesuai kebutuhan kebutuhan, minat - minat dan gaya belajar anak. Anak - anak dapat mengikuti atau belajar pada pendidikan pra sekolah dengan memilih sekolah yang dapat memenuhi kebutuhan tumbuh kembangnya termasuk diantaranya adalah pengenalan konsep diri.

Konsep diri atau self concep merupakan pandangan dan perasaan tentang diri. Persepsi tentang diri sendiri tentang siapa dan apa itu dia. Konsep ini seperti bayangan cermin ditentukan sebagian besar oleh peran dan hubungan orang lain. Anak - anak perlu mengenal siapa dirinya dimulai dengan segala sesuatu yang melekat pada dirinya seperti nama lengkapnya, jenis kelaminnya, keluarganya dan juga hal yang berhubungan dengan perkembangan psikisnya seperti mengenal perasaannya sendiri baik itu gembira, suka cita maupun bingung, cemas bahkan sedih sekalipun. Konsep diri ini meliputi konsep diri baik positif maupun negatif.

Perbedaan pendidikan di rumah dan di sekolah menjadi tolok ukur keberhasilan pembentukan konsep diri positif pada anak. Orang tua cenderung sepenuhnya mempercayakan anak - anaknya di sekolah dan kurang memperhatikan kebutuhan psikisnya ketika di rumah. Banyak orang tua bekerja dan larut dalam kesibukannya masing - masing. Data dari PAUD full day yang berada di kota Semarang ini menyatakan bahwa 60 persen dari peserta didik adalah kedua orang tuanya yang sibuk bekerja. Kondisi seperti ini menyebabkan adanya ketidakselarasan pendidikan di sekolah dan pengasuhan di rumah. Pembentukan konsep diri positif anak memerlukan waktu yang terus - menerus dan contoh - contoh kongkrit sederhana yang mampu membuat anak mengerti siapa dirinya. Ketika konsep diri sudah mulai terbangun di sekolah tetapi disisi lain tidak ada kelanjutan edukasi mengenai konsep diri di rumah maka akan menjadi hambatan tersendiri bagi anak dalam mengenali siapa dirinya.

Orang tua cenderung bertahan dengan harapan dan keinginannya terhadap anak tanpa memahami kebutuhan dan kesiapan anak menerima kondisi yang kurang menyenangkan dalam kehidupannya. Berbeda ketika di sekolah anak belajar mengenal dirinya melalui tema - tema dan beragam kegiatan. Ragam main yang menyenangkan membuat anak merasa tercukupi dan terpenuhi kebutuhan yang semestinya. 


\section{KAJIAN TEORI}

\section{Konsep Diri Anak}

Membangun konsep diri positif bagi anak adalah sepatutnya dilakukan. Peran pendidik di sekolah adalah mencari metode dan media pembelajaran yang tepat bagi anak dengan memahami perbedaan kondisi dan latar belakang serta kronologis kehidupan anak termasuk kondisi keharmoniasan kehidupan orang tua, keadaan ekonomi orang tua, jumlah saudara kandung dan perhatian yang diberikan orang tua terhadap anak (Meriana, 2010). Di Indonesia pembelajaran pendidikan prasekolah lebih bersifat akademik, di mana anak lebih banyak duduk di bangku dan harus tertib seperti di sekolah. Jarang guru memberikan kesempatan kepada anak untuk berksplorasi, mengekspresikan perasaannya, dan melakukan sendiri apa yang mereka minati, sampai menemukan pemecahan masalah sendiri. Apabila kondisi tersebut terus menerus dilakukan tanpa upaya perbaikan maka yang terjadi adalah terjadinya maladaptive pada developmentally appropriate practise ditandai tidak adanya keberhasilan perkembangan sesuai dengan kecocokan usianya termasuk konsep diri yang merupakan penentu dasar pada keberhasilan perkembangan selanjutnya. Hal tersebut perlu upaya penanganan yang tepat.

\section{Media Visual}

Perkembangan teknologi informasi melalui media visual menjadikan daya tarik tersendiri bagi anak untuk memenuhi rasa ingin tahunya dan mencoba terlibat di dalamnya dengan experential learning belajar melalui pengalaman (Calhoun, 2014). Pemanfaatan kemajuan teknologi informasi ini hendaknya diupayakan oleh pendidik sebagai salah satu media pembelajaran yang menyenangkan bagi anak dalam mengenal konsep dirinya. Penggunaan media ini dikemas dalam multimedia pembelajaran yang komprehensif serta inovatif dan dapat diaplikasikan orang tua di rumah sehingga tercipta keselarasan pembelajaran di sekolah dan di rumah tanpa anak mengalami kejenuhan. Perlu dilakukan penelitian dimaksudkan ingin mengetahui lebih lanjut peran mulimedia pembelajaran dalam pengenalan konsep diri anak usia $2-6$ tahun.

\section{METODE}

Penelitian ini dilaksanakan dengan pendekatan kualitatif-fenomenologi. Variabel dalam penelitian ini adalah konsep diri dan digital learning. Subyek penelitian yang digunakan adalah anak usia $2-6$ tahun di KB - TK Annida Ya Fatimah Jepat Lor Tayu Pati. Instrumen penelitian menggunakan tehnik trianggulasi yaitu wawancara, dokumentasi dan observasi terhadap subyek penelitian. Peneliti melakukan wawancara terhadap para guru terhadap keberhasilan pembelajaran konsep diri anak. Terdapat beberapa catatan penting yang perlu dilakukan tindakan lebih lanjut yaitu dengan cara observasi untuk memperoleh data secara lengkap. Penelitian ini memerlukan kecermatan dan strategi dalam konsistensi terhadap fokus penelitian hal ini disebabkan banyak permasalahan yang perlu dicarikan solusi dan penanganan yang muncul dalam proses pembelajaran. Pengenalan konsep diri anak memerlukan media pembelajaran yang kritis dan aplikatif dalam mengatasi permasalahan yang muncul dalam proses pembelajaran. Menurut Rachman (2011 : 149) Penelitian ini juga disebut penelitian kualitataif karena data yang terkumpul dan analisisnya lebih bersifat kualitatif. Obyek dalam penelitian kualitatif adalah obyek yang alamiah yaitu obyek yang apa adanya tidak ada manipulasi dari peneliti. Penelitian ini menggambarkan fenomena secara mendalam dan kompleks, sehingga diperlukan pemahaman yang utuh dan tidak bisa dipisahkan dari konteksnya dengan permasalahan yang hendak dikaji, yaitu permasalahan klasik pendidikan, mutu, relevansi, efektifitas, dan pemerataan yang masih terus ada hingga kini. 


\section{HASIL PENELITIAN}

\section{Batasan dan implikasi Pengenalan Konsep Diri Anak Melalui Visual Learning}

Rogers dalam Alwisol (2008) konsep diri merupakan bagian sadar dari ruang fenomenal yang didasari dan disimbolisasikan yaitu "aku". Merupakan pusat referensi setiap individu yang perlahan lahandibedakan dan disimbolisasikan sebagai bayangan tentang diri yang mengatakan apa dan siapa aku sebenarnya dan apa sebenarnya yang harus aku perbuat. pembentukan konsep diri memudahkan interaksi sosial sehingga individu yang bersangkutan dapat mengantisipasi reaksi orang lain. Pola kepribadian yang dasarnya telah diletakkan pada masa bayi, mulai terbentuk dalam awal masa kanakkanak. Orang tua, saudara kandung dan sanak saudara lainnya merupakan dunia sosial bagi anak-anak, maka bagaimana perasaan mereka kepada anak- anak dan bagaimana perlakuan mereka merupakan faktor penting dalam pembentukan konsep diri, yaitu inti pola kepribadian.

Konsep diri atau self concept tidaklah bawaan sejak lahir, melainkan hasil dari proses belajar. Saat manusia mengenal lingkungannya, maka saat itu pula dia belajar berbagai hal mengenai kehidupan. Berdasarkan pengalaman hidupnya, seorang individu akan menetapkan konsep dirinya berdasarkan berbagai faktor. Menurut Hurlock (2009) faktor yng mempengaruhi konsep diri tersebut diataranya yaitu bentuk tubuh, cacat tubuh, pakaian, nama dan julukan, inteligensi kecerdasan, taraf aspirasi/citacita, emosi, jenis/gengsi sekolah, status sosial, ekonomi keluarga, teman dan tokoh/orang yang berpengaruh.

Apabila faktor-faktor tersebut cenderung menimbulkan perasaan yang positif seperti bangga atau senang maka akan muncul konsep diri yang positif. Pada masa kanak-kanak seorang individu umumnya cenderung menganggap benar apa saja yang dikatakan oleh orang lain.

Menurut Symonds (dalam Agustiani,2006) seorang anak merasa diterima, dihargai dan dicintai maka anak tersebut akan menerima, menghargai dan juga mencintai dirinya (berkonsep diri positif). Dan akan sebaliknya, jika orang yang berpengaruh di sekelilingnya seperti orang tua, guru, orang dewasa, teman dan lain sebagainya ternyata meremehkan, merendahkan, mempermalukan dan menolaknya, maka pengalaman tersebut akan disikapi dengan negatif dan akan memunculkan konsep diri yang negatif. Orang lain yang dapat mempengaruhi konsep diri seseorang (Calhoun \& Acolela, 1990) adalah orang tua, teman sebaya dan masyarakat.

William D.Brooks (dalam Rahkmat, 2005:105) bahwa dalam menilai dirinya seseorang ada yang menilai positif dan ada yang menilai negatif. Maksudnya individu tersebut ada yang mempunyai konsep diri yang positif dan ada yang mempunyai konsep diri yang negatif. Individu yang memiliki konsep diri negatif meyakini dan memandang bahwa dirinya lemah, tidak berdaya, tidak dapat berbuat apa-apa, tidak kompeten, gagal, malang, tidak menarik, tidak disukai dan kehilangan daya tarik terhadap hidup. Individu yang memiliki konsep diri positif_bersikap optimis, percaya diri sendiri dan selalu bersikap positif terhadap segala sesuatu, juga terhadap kegagalan yang dialami. Kegagalan tidak dipandang sebagai akhir segalanya, namun dijadikan sebagai penemuan dan pelajaran berharga untuk melangkah kedepan. Anak - anak yang terbentuk konsep diri positif sejak dini akan mampu menghargai dirinya sendiri dan melihat hal-hal yang positif yang dapat dilakukan demi keberhasilan di masa yang akan datang.

\section{Tabel 1.}

Tahapan Instruksi Implementasi Konsep Diri Anak (Omrod, 2008)

\begin{tabular}{lll} 
Tahapan & Performa Tugas & Instruksi Tugas \\
\hline Tahap 1: & Guru menunjukkan gambar visual & Guru memberikan instruksi \\
Cognitive & sesuai tema. Misalnya gambar anak dengan kata-kata dan contoh \\
modeling & laki - laki, gambar anak perempuan, konkrit melalui visual
\end{tabular}




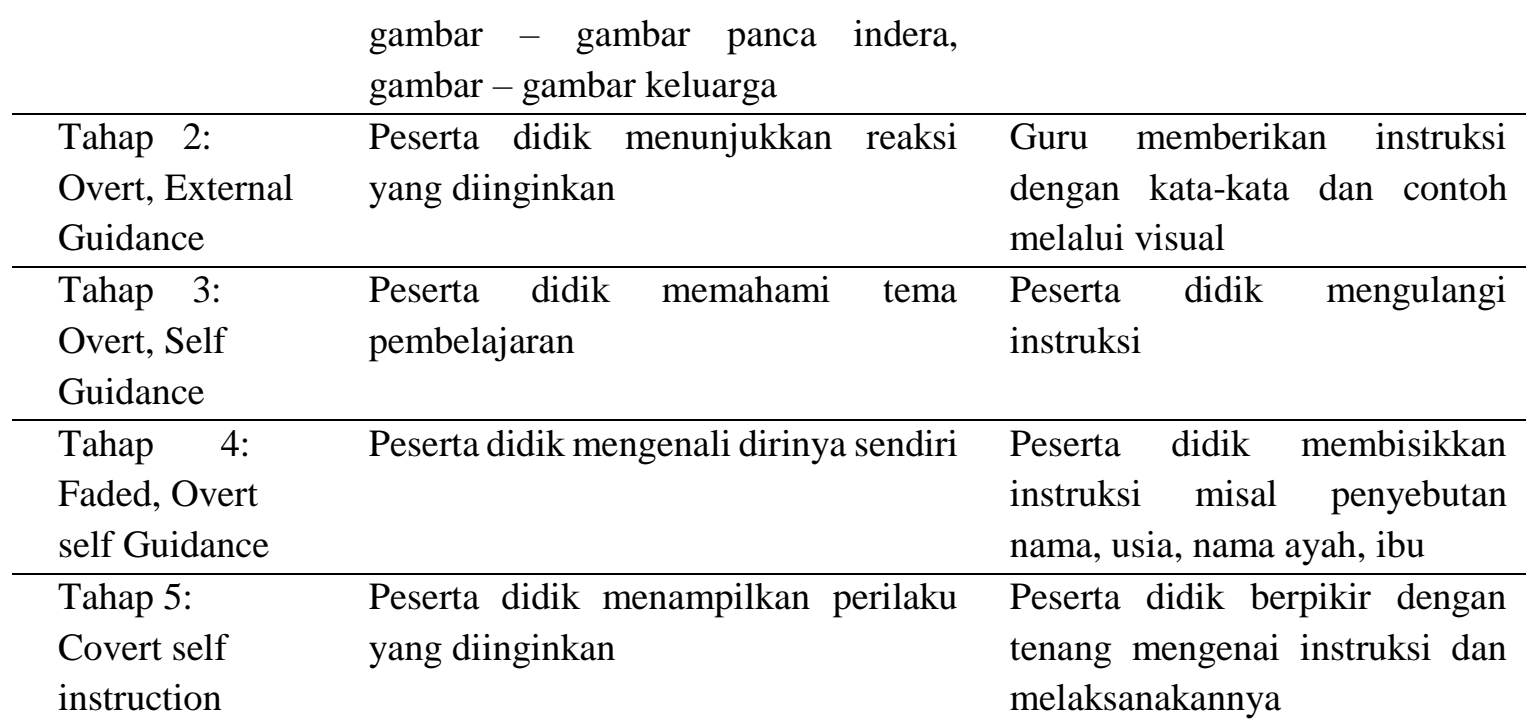

\section{DISKUSI}

Media pembelajaran (Anitah, 2009) adalah segala sesuatu yang dapat digunakan untuk merangsang pikiran, perasaan, perhatian, dan kemauan anak sehingga dapat mendorong terjadinya proses belajar pada diri anak.Media pembelajaran yang baik harus memenuhi beberapa syarat. Media pembelajaran harus meningkatkan motivasi peserta didik. Penggunaan media mempunyai tujuan memberikan motivasi kepada peserta didik. Media visual merupakan penyampaian pesan atau informasi secara teknik dan kreatif yang mana menampilkan gambar, grafik serta tata dan letaknya jelas. Media visual dibedakan menjadi dua yaitu:

1) Media visual yang tidak diproyeksikan antara lain: gambar mati atau gambar diam, ilustrasi, karikatur, bagan, diagram, grafik, peta datar, realita dan model.

2) Media visual yang diproyeksikan antara lain: Overhead Projector (OHP), Slide (film bingkai),

Flimstrip (film rangkai), opaqueprojector.

Keberadaan media dalam suatu aktivitas pendidikan mempunyai fungsi untuk menjelaskan penyajian suatu informasi serta untuk mengatasi keterbatasan dari informasi yang disampaikan tersebut, sehingga obyek yang terlalu besar, obyek yang terlalu kecil, atau obyek yang terlalu komplek, serta konsep yang terlalu luas dan peristiwa yang terjadi dimasa lalu dapat ditransformasikan kepada penerima pesan (peserta didik) secara efektif.

\section{Tabel 2.}

Implementasi visual learning pada pengenalan konsep diri anak

\begin{tabular}{|c|c|c|c|}
\hline No. & Komponen & Materi & Media \\
\hline 1. & Perencanaan & $\begin{array}{l}\text { Tema pembelajaran diri } \\
\text { sendiri dan keluarga }\end{array}$ & $\begin{array}{l}\text { Gambar Visual tentang } \\
\text { tentang diri sendiri dan } \\
\text { keluarga }\end{array}$ \\
\hline 2. & Pelaksanaan & $\begin{array}{l}\text { Anak menyebutkan nama, } \\
\text { jenis kelamin, makanan } \\
\text { kesukaan, dan nama - nama } \\
\text { keluarga }\end{array}$ & $\begin{array}{l}\text { Visualisasi gambar } \\
\text { melalui media grafis dan } \\
\text { model }\end{array}$ \\
\hline 3. & Evaluasi & Recalling tema & Flash back gambar \\
\hline
\end{tabular}




\section{KESIMPULAN}

Masa usia dini menjadi tolok ukur keberhasilan penanaman konsep diri pada anak. Anak mengenal dan memahami dirinya sendiri diawali dengan hal - hal yang sederhana dan berada pada lingkungan sekitarnya. Begitupun dalam proses pembelajaran di sekolah harus diperhatikan gaya belajar anak. Media visual memiliki daya tarik tersendiri bagi anak dengan memanfaatkan perkembangan teknologi dan informasi. Penyajian media visual lebih dapat diterima oleh anak dengan tampilan kreativitas grafis dan model sehingga penanaman konsep diri yang membutuhkan ketelitian serta kejelian dengan menyesuaikan perkembangan usia anak yang beragam khususnya anak usia $2-6$ tahun.

Anak yang terbentuk konsep diri sejak dini akan positif dalam penerimaan diri dengan segala kelebihan dan kekurangan. Konsep diri positif mengantarkan anak pada pribadi yang tangguh serta semangat hidup dan optimisme menghadapi permasalahan dan pemecahannya. Sebaliknya jika konsep diri anak negatif maka anak selalu memiliki perasaan takut, cemas dan menyerah pada keadaan yang menyulitkannya tanpa berusaha terlebih dahulu. Untuk itu sangat penting mengenalkan konsep diri anak sejak dini.

\section{REFERENSI}

Alwisol, (2008). Psikologi Kepribadian, Malang : UPT UMM

Anitah, Sri. (2009). Media Pembelajaran. Surakarta. UNS Press.

Calhoun, JF \& Acocella, J.R. (2014). Psychology of Adjusment and Human Relationship. New Jurnal Psikologi. No. 1, 75-102.

Hendriani, Agustiani. (2006). Psikologi Perkembangan. Bandung : Refika Aditama

Hurlock, Elizabeth. (2009). Psikologi Perkembangan. Jakarta : Erlangga

Mariyana, Rita, Dkk. (2010). Pengelolaan Lingkungan Belajar. Jakarta. Prenada Media.

Omrod, J.E. (2008). Psikologi Pendidikan. Jakarta : Erlangga

Rachman, Maman (2011). Metode Penelitian Pendidikan Moral. Semarang : Unnes Press

Rakhmat, Jalaludin. (2002). Psikologi Komunikasi, Bandung : PT. Remaja. Rosdakarya. 